Arq. Bras. Med. Vet. Zootec., v.69, n.3, p.529-534, 2017

\title{
Use of different pressures for transvaginal follicular aspiration in mares
}

\author{
[Uso de diferentes pressões para aspiração folicular transvaginal em éguas] \\ M.A.F. Sá, S.O. Paiva, G.A. Dutra, C.G. Barbosa, M.R.B. Mello, J.C.F. Jacob \\ Universidade Federal Rural do Rio de Janeiro - Rio de Janeiro, RJ
}

\begin{abstract}
The success of transvaginal follicular aspiration in mares can be influenced by several factors, such as vacuum pump pressure levels. The present study aimed to investigate the effect of different negative pressures $(150,280$ and $400 \mathrm{mmHg}$ ) of the vacuum pump on the oocyte recovery in the mares. The mares $(\mathrm{n}=10)$ were undergoing follicular aspiration using three different negative pressures for three consecutive estrous cycles as follows: $\mathrm{G} 150=150 \mathrm{mmHg}(\mathrm{n}=10) ; \mathrm{G} 280=280 \mathrm{mmHg}(\mathrm{n}=10) ; \mathrm{G} 400=400 \mathrm{mmHg}$ $(n=10)$. Every estrous cycle, the group that the mare would participate was drawn, and each animal participated once in each group. Only preovulatory follicle was used, about 30 to 36 hours after application of hCG. To compare the results, the chi-square test was used (5\% significance) and Fisher exact test, when recommended. Thirty preovulatory follicles (diameter $36.1 \pm 1.80 \mathrm{~mm}$ ) were aspirated and ten oocytes were recovered (33.3\%). There was no statistical difference between the experimental groups $(\mathrm{p}=0.59)$. Thus, accord to the results observed in this study, we could conclude that the negative pressure of the vacuum pump used was not efficient to increase oocyte recovery.
\end{abstract}

Keywords: oocyte, subfertility, preovulatory follicle, hCG

\section{RESUMO}

O sucesso da técnica de aspiração folicular transvaginal em éguas pode ser influenciado de maneira determinante por diversos fatores, tais como níveis de pressão da bomba de vácuo. Diante disso, o presente experimento visou investigar o efeito de diferentes pressões negativas $(150,280$ e 400 $\mathrm{mmHg}) \mathrm{da}$ bomba de vácuo sobre a taxa de recuperação de oócitos em éguas. As éguas $(n=10)$ foram submetidas à aspiração folicular utilizando-se três diferentes pressões negativas por três ciclos estrais consecutivos, da seguinte maneira: $G 150=150 \mathrm{mmHg}(n=10) ; G 280=280 \mathrm{mmHg}(n=10) ; G 400=400 \mathrm{mmHg}(n=10)$. A cada ciclo estral, sorteava-se o grupo do qual a égua participaria, sendo que cada animal integrou um grupo somente uma vez. Foi puncionado somente folículo pré-ovulatório, em torno de 30 a 36 horas após a aplicação do hCG. Os resultados foram comparados utilizando-se o teste qui-quadrado (a $5 \%$ de significância) e o Fisher Exato, quando recomendados. Foram aspirados 30 folículos pré-ovulatórios (diâmetro $36,1 \pm 1,80 \mathrm{~mm}$ ) e recuperados 10 oócitos (33,3\%). Não houve diferença estatística entre os grupos experimentais $(P=0,59)$. Dessa forma, mediante os resultados obtidos no presente estudo, foi possível concluir que a pressão negativa da bomba de vácuo utilizada não se mostrou determinante para elevar a recuperação oocitária.

Palavras-chave: oócito, subfertilidade, folículo pré-ovulatório, $h C G$

\section{INTRODUCTION}

Mares with reproductive handicap or difficulties as embryo donors may be submitted to follicular aspiration to obtain viable oocytes and manage reproductive deficiencies (Bogh et al., 2003). The most commonly used technique is currently ultrasound guided transvaginal aspiration (Carnevale, 2004).

Recebido em 10 de agosto de 2016

Aceito em 10 de outubro de 2016

E-mail: marcus.ferreira85@hotmail.com 
Oocytes can be fertilized in vivo through oocyte transfer technique (OT) in which they are surgically transferred to the recipient mare's uterine tube through laparotomy. Fecundation occurs through artificial insemination of the recipient mare 12 hours prior, using a conventional concentration for the inseminating dose (Carnevale et al., 2000; 2001; 2002). Oocytes can be destined to gamete intrafallopian transfer (GIFT), which follows the same protocol as OT; however, artificial insemination is performed directly in the uterine tube, near the oocyte, using low concentration semen (Carnevale, 2004).

Currently, the most common biotechnique to obtain equine oocytes consists in transvaginal follicular aspiration guided by ultrasound. Success depends on several factors such as pressure level in the vacuum pump, type of needle used, anesthetic protocols, phase of estrus cycle at puncture time, and practitioner experience, among others.

Authors report different rates of oocyte recovery using negative pressure of up to $300 \mathrm{mmHg}$ : Carnevale et al. (2001), 70\% (39/56); Carnevale et al. (2003), 76\% (331/434); Mari et al. (2005), $30.8 \%$ (16/52); Carnevale et al. (2005), 77\% $(548 / 710)$. Use of higher pressure could be a resource to obtain more oocytes. However, some authors state that this would lead to loss of cumulus cells and damage to oocytes (Kanitz et al., 1995; Pycock, 1996).

This experiment aimed to investigate the effect of different vacuum pump negative pressures $(150,280$, and $400 \mathrm{mmHg})$ on equine oocyte recovery rates.

\section{MATERIAL AND METHODS}

The study is in accordance to Law 11.794 of October $8^{\text {th }}$ of 2008 , with the Decree 6.899 of July $15^{\text {th }}$ of 2009 , with the norms of the National Council for Control of Animal Experiments (CONCEA) and approved by the Ethics Committee of Animal Use of the Institute of Veterinary and the Federal Rural University of Rio de Janeiro (CEUA/IV/UFRRJ), protocol number 7217250615

The study was carried out at Animal Reproduction Area of DRAA/IZ/UFRRJ located in the municipality of Seropedica (LAT $22^{\circ} 46^{\prime} 17.44^{\prime \prime} \mathrm{S}$ and LONG. 4340'25.98" O), Rio de Janeiro state. Ten cycling mares were used as oocyte donors, all weighing between 270 and $440 \mathrm{~kg}$. These animals were kept enclosed with grass, salt, and fresh water ad libitum, and supplemented daily with concentrated ration (12\% P.B), $1.0 \%$ P.V.

All mares were submitted to follicular aspiration using three different negative pressures for three consecutive estrous cycles as follows: G150= $150 \mathrm{mmHg}(\mathrm{n}=10) ; \mathrm{G} 280=280 \mathrm{mmHg}(\mathrm{n}=10)$; $\mathrm{G} 400=400 \mathrm{mmHg}(\mathrm{n}=10)$. At each estrous cycle, the group to which the mare would belong was drawn, and each animal was only part of a group once.

Daily monitoring of uterine and ovarian activity of the mares through transrectal ultrasonography was performed during estrous until endometrial edema was $\geq 3,0$ (Pycock et al., 2006) and the largest follicle reached at least $35 \mathrm{~mm}$ of diameter, at which time 1000UI of human Chorionic Gonadotrophin (hCG) (Chorulon $^{\circledR}$, MSD Saúde Animal, Brasil) was administered intravenously (Jacob et al., 2011).

For follicular aspiration, mares were sedated using $0.5 \mathrm{mg} / \mathrm{kg}$ of Xilazine Cloridrate $10 \%$, $0.01 \mathrm{mg} / \mathrm{kg}$, IV, of Detomidine Cloridrate. For rectal muscle relaxation, $0.2 \mathrm{mg} / \mathrm{kg}$ of Hyoscine N-butyl bromide (Butilescopolamine) was used. Mares received two doses of $1 \mathrm{mg} / \mathrm{kg}$ of Flunixin Meglumine, IV, the first before follicular aspiration procedure and the second 24 hours after the procedure, for analgesic and anti-inflammatory purposes. Enrofloxacine $10 \%$ $\left(5 \mathrm{mg} / \mathrm{kg}\right.$; Flotril $^{\circledR} 10 \%$, MSD Saúde Animal, Brasil) was used for three days, once per day, intramuscularly (IM) for antibiotic treatment.

The preovulatory follicle of the all mares was punctured 30 to 36 hours following hCG application, so oocytes would be in the final stage of maturation. For transvaginal aspiration, an ultrasound (Midray DPS 2200 Vet, São Paulo, Brazil) equipped with a convex transductor of $6.5 \mathrm{mHz}$ with a polyethylene guide with a double lumen 12-gauge needle $\left(\right.$ Cook $^{\circledR}$ EchoTip $^{\circledR}$ Double Lumen Aspiration Needle).

Follicular antrum was washed in continuous flux with $180 \mathrm{ml}$ of DPBS (Dulbelcco's phosphate 
buffered saline) supplemented with $10 \mathrm{UI} / \mathrm{mL}$ of heparin to avoid adherence and $1 \%$ of bovine fetal serum. The equipment and environment that had contact with the oocyte during manipulation was kept at $380 \mathrm{C}$. The aspirated follicular content was transferred to a Petri dishes $(146 \times 21 \mathrm{~mm})$ and carefully examined at the stereomicroscope $(40 x)$ for oocyte localization.

Oocytes were classified based on their morphology, using a stereomicroscope, according to Gonçalves et al. (2008), where: grade 1 (presence of compact cumulus, containing over three layers of cells, ooplasm with fine and homogeneous granulation, filling interior of the pellucid zone with brown coloring); grade 2 (partial presence of compact cumulus around the oocyte or completely surrounding the oocyte with less than three cellular layers, and ooplasm with heterogenous granulation distribution, higher concentration in the center and less color in the periphery or condensed in a single spot, with the appearance of a dark spot. Ooplasm fills the interior space of the pellucid zone); grade 3 (presence of expanded cumulus. Ooplasm contracted, degenerated, with vacuoles or fragmented with spaces between the cellular membrane and pellucid zone, irregular filling of perivitelline space; grade 4: oocyte is nude, without cumulus.

Q-Square test (5\% of significance) and Exact Fisher test were performed, when appropriate, to evaluate the effect of different negative pressures of vacuum pump on oocyte recovery.

\section{RESULTS AND DISCUSSION}

From the three groups, 30 preovulatory follicles were aspirated (average follicular diameter of $36.1 \pm 1.80 \mathrm{~mm}$ ) and ten oocytes were recovered (33.3\%) (Tab.1). No statistic difference was observed between experimental groups $(\mathrm{p}=0.59)$. Aspiration sessions occurred $32.5 \pm 1.9 \mathrm{~h}$ after administration of hCG.

Table 1. Rate of oocyte recovery in mares in transvaginal follicular aspiration sessions using different negative pressures from vacuum pumps $(150,280$, and $400 \mathrm{mmHg})$

\begin{tabular}{c|cccc}
\hline & G150 & G280 & G400 & Total \\
\hline $\begin{array}{c}\text { Oocytes per } \\
\text { group }\end{array}$ & $40.0 \%(4 / 10)$ & $40.0 \%(4 / 10)$ & $20.0 \%(2 / 10)$ & $33,3 \%(10 / 30)$ \\
\hline
\end{tabular}

No statistically significant difference ( $\mathrm{p}>0.05)$.

A review of available literature shows ample variation in oocyte recovery rates. From $8 \%$ to $85 \%$ of recovery rates have been described (Pycock, 1996; Araújo, 2015; Carnevale et al., 2001). The recovery rate found in this study was of $33.3 \%$, which is within the range reported in the literature.

The results obtained in the present study were lower than those found by Silva et al. (2004) at $74 \%$ and Carnevale et al. (2005) at $77 \%$ of oocyte recovery rate. However, they were higher to those in previous Brazilian studies as reported by Rodrigues (2006) who obtained $7.5 \%$ of oocyte recovery and Blanco et al. (2009), who obtained $13.7 \%$.

Many factors can influence oocyte recovery rates during technique application. According to Hafez and Hafez (2004), turbulence due to follicular wash can facilitate oocyte liberation in preovulatory follicles if the cumulus and granulosa cells present a loose connection due to the final maturation process. Shabpareh et al. (1993) and Mari et al. (2005) observed significant difference in oocyte recuperation between washed and unwashed follicles (44\% compared to $24 \%$ and $47 \%$ compared to $12.5 \%$ respectively). McKinnon et al. (1988) also observed increased oocyte recovery rates when follicles were washed during flank aspiration when the animals were in a standing position. At aspiration, in this study, follicular fluid was aspirated separately, where oocytes were not found. All oocytes were localized in DPBS used for follicle wash. Follicle wash was also recommended by Hinrichs et al. (1990) who reported that $50 \%(12 / 24)$ of oocytes were found in the wash fluid.

Negative pressure in the vacuum pump can be an important factor to influence oocyte recovery. Mari et al. (2005) obtained 30.8\% (16/52) of oocyte recovery using a negative pressure of 
$150 \mathrm{mmHg}$ to aspirate follicles with a preovulatory diameter of over $35 \mathrm{~mm}$. However, the authors did not use maturation agents for follicular and oocyte maturation, unlike the methodology of the present study. With the same negative pressure of $150 \mathrm{mmHg}$ in a vacuum pump, the oocyte recovery rate in the present experiment was of $40 \%$ (4/10), higher than that observed by Mari et al. (2005).

A commercial program established in the University of Colorado obtained expressive rates of oocyte recovery through follicle aspiration: $70 \%(39 / 56)$ of recovery in 1998 and 1999 (Carnevale et al., 2001), 76\% (331/434) between 2000 and 2002 (Carnevale et al., 2003) and 77\% (548/710) when data from the years 2000 and 2004 were analyzed (Carnevale et al., 2005). In that period follicles with preovulatory diameter ( $\geq 35 \mathrm{~mm}$ ) were aspirated using $150 \mathrm{mmHg}$ of pressure. The dose of hCG was of 1500 to 2500UI and, at times, was associated to Deslorelin Acetate (2,1 mg), unlike the protocol of this study. Scott et al. (2001) used a protocol like the one of Carnevale et al. (2001; 2003; $2005)$ and obtained a $43 \%(16 / 37)$ of oocyte recovery. Despite the use of 2000UI of hCG, Scott et al. (2001) reported that the low oocyte recovery rate may have been because some mares did not respond to gonadotrophin use since $50 \%$ of recovered oocytes had a compact cumulus cell layer.

The authors also affirmed that lack of technician experience may influence results, which may also have influenced the results of this study. Although this study used a lower dose of hCG (1000UI) than the doses described in studies in literature, oocyte recovery rate was within the range described in literature (8 to $85 \%$ ). This result was higher than some studies in which a higher dose of hCG was used, which demonstrates that this is not the main factor for oocyte recovery. Furthermore, of the recovered oocytes, only $10 \%(1 / 10)$ had compact cumulus cells, which means that most mares responded to the use of 1000UI of hCG. One of the recovered oocytes was nude at G400 (Tab. 2).

Oocyte recovery rate in the G280 $(40 \%, 4 / 10)$ was lower that observed by Bogh et al. (2002), who reached $68 \%(15 / 22)$ using a simple lumen needle and negative pressure between 200 and $300 \mathrm{mmHg}$. The authors sought to evaluate, among other things, the influence of Equine Pituitary Extract (25mg, IV) on in vitro maturation. This extract had eFSH and eLH in its formulation, which may have influenced oocyte recovery rates. Oocyte recovery in the present study was higher than that observed by Duchamp et al. (1995), who recovered 18\% (14/77) of follicles with diameters between 20 and $30 \mathrm{~mm}$ using $300 \mathrm{mmHg}$ of pressure.

Oocyte recovery rate at G400 was also higher than that obtained by Kanitz et al. (1995), this being the only study found in the literature with this pressure for follicle aspiration in mares, reporting $8.3 \%(1 / 12)$ for follicles measuring over $30 \mathrm{~mm}$. This pressure was associated to loss of cumulus cells in oocytes according to Kanitz et al. (1995). The present study could not conclude that high pressure was responsible for cumulus cell loss due to the small sample of oocytes obtained in this group. However, it is possible that this pressure ruptured some oocytes during the procedure, in which follicular content had high cell concentration, without locating the oocyte.

The dose of hCG used by Meintjes et al. (1995) was chosen according to preovulatory follicle diameter. For follicles measuring 32 to $35 \mathrm{~mm}$, the authors used 1500UI of hCG and, for diameters between 35 and $38 \mathrm{~mm}, 2500 \mathrm{UI}$. However, the recovery rate obtained for each dose was not divulged, since the goal of the study was to compare oocyte recovery rates between pony mares with follicles in development $(46.8 \%, 29 / 62)$, mares with preovulatory follicles $(42.9 \%, 12 / 28)$, and impregnated mares $(25 / 33,76 \%)$, which was significantly higher. In the present study, the dose of 1000UI of hCG was chosen based on previous results of ovulatory rates $(89.52 \%$, 111/124) obtained by Jacob et al. (2011) up to 48 hours after the administration of 1000UI.

With a dose of 2500UI of hCG, 50.7\% (33/65) of oocyte recovery of preovulatory follicles was reached (Franz et al., 2001). However, the inadequate answer to hCG (recovery of nonexpanded oocytes) was also highlighted as a possible cause of low oocyte recovery rates when compared to other reports in the literature.

Most oocytes $(90 \%, 9 / 10)$ in this experiment were classified as grade $1(80 \%, 8 / 10)$ or grade 2 
$(10 \%, 1 / 10)$. This percentage was closer to that found by Cook et al. (1992), who classified 89\% $(8 / 9)$ of recovered oocytes as good and only one oocyte was considered degenerated. The present study found only one grade 4 (nude) oocyte in the G400 group (Tab. 2), which corresponds to $50 \%(1 / 2)$ of recovered oocytes in this group. Due to the small number of recovered oocytes, it was not possible to affirm that this was due to high pressure. Table 2 shows the distribution of oocytes according to quality.

Table 2. Morphology of equine recovered oocytes in transvaginal follicle aspiration sessions using different negative pressures in the vacuum pump $(150,280$, and $400 \mathrm{mmHg})$

\begin{tabular}{c|ccc}
\hline Classification & $\mathrm{G}_{150}$ & $\mathrm{G}_{280}$ & $\mathrm{G}_{400}$ \\
\hline Grade 1 & $\begin{array}{c}100 \% \\
(4 / 4)\end{array}$ & $\begin{array}{c}75 \% \\
(3 / 4)\end{array}$ & $\begin{array}{c}50 \% \\
(1 / 2)\end{array}$ \\
\hline Grade 2 & - & $\begin{array}{c}25 \% \\
(1 / 4)\end{array}$ & - \\
\hline Grade 3 & - & - & - \\
\hline Grade 4 & - & - & $\begin{array}{c}50 \% \\
(1 / 2)\end{array}$ \\
\hline
\end{tabular}

As to the fertility of the mares used in this study, no infection, adherence, abscess, or inflammatory reaction was observed, which provides evidence that the protocol utilizing antibiotic and anti-inflammatory was adequate. The mares also maintained regular estrous cycles with no apparent alteration in fertility, although they were not covered or inseminated, as described by Mari et al. (2005), where a $70 \%$ (7/10) gestation rate was found after OPU. Bruck et al. (1997) aspirated follicles for five consecutive estrous cycles in two different intervals every six and every 23 days, showing that aspirations had lower oocyte recovery when performed every six days. In the present study, the interval between aspiration follicle sessions was of $17,4 \pm 3,9$ days since only preovulatory follicles were aspirated. In all cycles, ultrasound showed a structure compatible with corpus luteum after aspiration.

\section{CONCLUSION}

The results of the present study allow for the conclusion that negative pressure in vacuum pumps was not a determinant for oocyte recovery rates.

\section{ACKNOWLEDGEMENT}

To Fundação Carlos Chagas Filho de Amparo à Pesquisa do Estado do Rio de Janeiro (FAPERJ).

\section{REFERENCES}

ARAÚJO, R.R. Estudo em larga escala dos efeitos da idade sobre os parâmetros reprodutivos e viabilidade de oócitos equinos após injeção intracitoplasmática de espermatozóide (ICSI) usando sêmen sexado. 2015. 108f. Tese (Doutorado) - Faculdade de Medicina Veterinária e Zootecnia, Campus São Paulo, SP.

BLANCO, I.D.P.; DEVITO, L.G.; FERREIRA, H.N. et al. Aspiration of equine oocytes from immature follicles after treatment with equine pituitary extract (EPE) alone or in combination with hCG. Anim. Reprod. Sci., v.114, p.203-209, 2009.

BOGH, I.B.; BÉZARD, J.; DUCHAMP, G. et al. Pure preovulatory follicular fluid promotes in vitro maturation of in vivo aspirated equine oocytes. Theriogenology, v.57, p.1765-1779, 2002.

BOGH, I.B.; BRINK, P.; JENSEN, H.E. et al. Ovarian function and morphology in the mare after multiple follicular punctures. Equine Vet. J., v.35, p.575-579, 2003.

BRUCK, I.; SYNNESTVEDT, B.; GREVE, T. Repeated transvaginal oocyte aspiration in unstimulated and FSH-treated mares. Theriogenology, v.47, p.1157-1167, 1997.

CARNEVALE, E.M. Oocyte transfer and gameta intrafallopian transfer in the mare. Anim. Reprod. Sci., v.82, p.617-624, 2004.

CARNEVALE, E.M.; MACLELLAN, L.J.; SILVA, M.A.C. et al. Comparison of culture and insemination techniques for equine oocyte transfer. Theriogenology, v.54, p.981-987, 2000.

CARNEVALE, E.M.; MACLELLAN, L.J.; SILVA, M.A.C. et al. Equine sperm-oocyte interaction: results after intraoviductal and intrauterine inseminations of recipients for oocyte transfer. Anim. Reprod. Sci., v.68, p.305314, 2001. 
CARNEVALE, E.M.; SILVA, M.A.C.; MACLELLAN, L.J. et al. Effects of culture media and time of insemination on oocyte transfer. Theriogenology, v.58, p.759-762, 2002.

CARNEVALE, E.M.; SILVA, M.A.C.; PANZANI, D. et al. Factors affecting the success of oocyte transfer in a clinical program for subfertile mares. Theriogenology, v.64, p.519527,2005 .

CARNEVALE, E.M.; SILVA, M.A.C.; SQUIRES, E.L. How to collect and transfer oocytes. In: ANNUAL CONVENTION OF THE AMERICAN ASSOCIATION OF EQUINE PRACTITIONERS, 46., 2003, New Orleans. Proceedings... New Orleans: LA, 2003. p.293294.

COOK, N.L.; SQUIRES, E.L.; RAY, B.S. et al. Transvaginal ultrasonically guided follicular aspiration of equine oocytes: preliminary results. J. Equine Vet. Sci., v.12, p.104-107, 1992.

DUCHAMP, G.; BEZARD, J.; PALMER, E. Oocyte yield and the consequences of puncture of all follicles larger than 8 millimeters in mares. Biol. Reprod. Monogr. Ser., v.1, p.233-241, 1995.

FRANZ, L.C.; SQUIRES, E.L.; O`DONOVAN, M.K. et al. Collection and in vitro maturation of equine oocytes from estrus, diestrus and pregnant mares. J. Equine Vet. Sci., v.21, p.26-32, 2001.

GONÇALVES, P.B.D.; FIGUEIREDO, J.R.; FREITAS, V.J.F. Biotécnicas aplicadas à reprodução animal. 2.ed. São Paulo: Roca, 2008. $408 \mathrm{p}$.

HAFEZ, E.S.B.; HAFEZ, B. Reprodução animal. 7.ed. São Paulo:Manole, 2004, 513p.

HINRICHS, K.; KENNEY, D.F.; KENNEY, R.M. Aspiration of oocyte mature and immature preovulatory follicles in the mare. Theriogenology, v.34, p.107-112, 1990.

JACOB, J.C.F.; SANTOS, G.O.; SÁ, M.A.F.; OLIVEIRA, J.P. Uso clínico de hCG em um programa de transferência embriões equino: mitos e verdades. Hora Vet., v.30, p.9-13, 2011.

KANITZ, W.; BECKER, F.; ALM, H.; TORNER, H. Ultrasound-guided follicular aspiration in mares. Biol. Reprod. Monogr. Ser., v.1, p.225-231, 1995.
MARI, G.; BARBARA, M.; ELEONORA, L.; STEFANO, B. Fertility in the mare after repeated transvaginal ultrasound-guided aspirations. Anim. Reprod. Sci., v.88, p.299-308, 2005.

MCKINNON, A.O; CARNEVALE, E.M.; SQUIRES, E.L. et al. Heterogenous and xenogenous fertilization of in vivo matured equine oocytes. J. Equine Vet. Sci., v.8, p.143$147,1988$.

MEINTJES, M.; BELLOW, M.S.; PAUL, J.B. et al. Transvaginal ultrasound-guided oocyte retrieval in cyclic and pregnant horse and pony mares for a in vitro fertilization. Biol. Reprod. Monogr. Ser., v.1, p.281, 1995a.

PYCOCK, J.F. Recovery of oocytes using transvaginal ultrasound in the mare: current equipment, technique and applications. Arq. Fac. Vet. UFRGS, v.24, p.148-167, 1996.

PYCOCK, J.; SAMPER, J.C.; MCKINNON, A.O. Current therapy in equine reproduction. Missouri: [Elsevier], 2006.512p.

RODRIGUES, R. Aspiração folicular transvaginal guiada por ultrassom em equinos. 2006. 51f. Dissertação (Mestrado) - Faculdade de Veterinária, Campus de Porto Alegre, Universidade Federal do Rio Grande do Sul, RS.

SCOTT, M.A.; CARNEVALE, E.M.; MACLELLAN, L.J. et al. Embryo development rates after transfer of oocytes matured in vivo, in vitro, or within oviducts of mares. Theriogenology, v. 55, p. 705- 715, 2001.

SHABPAREH, V.; SQUIRES, E.L.; SEIDEL, JR. G.E.; JASKO, D.J. Methods for collecting and maturing equine oocytes in vitro. Theriogenology, v.40, p.1161-1175, 1993.

SILVA, M.A.C; CARNEVALE, E.M.; MACLELLAN, L.J. et al. Oocytes transfer in mare with intrauterine or intraoviductal insemination using fresh, cooled, and frozen stallion semen. Theriogenology, v.61, p.705-713, 2004. 